\title{
Engineering Geology of the
}

\section{Paducah East Quadrangle in}

\section{Kentucky}

GEOLOGICAL SURVEY BULLETIN 1258-A

Prepared in cooperation with the Kentucky Geological Survey

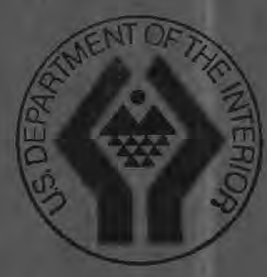





\section{Engineering Geology of the}

\section{Paducah East Quadrangle in}

\section{Kentucky}

By THOMAS C. NICHOLS, $J_{R}$.

CONTRIBUTIONS TO ENGINEERING GEOLOGY

GE OLOGICAL SURVEY BULLE T IN 1258-A

Prepared in cooperation with the Kentucky Geological Survey

$A$ field and laboratory study of

engineering behavior of earth

materials in an urban area

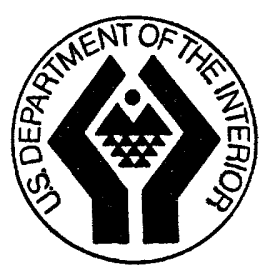


UNITED STATES DEPARTMENT OF THE INTERIOR

STEWART L. UDALL, Secretary

\section{GEOLOGICAL SURVEY}

William T. Pecora, Director 


\section{CONTENTS}

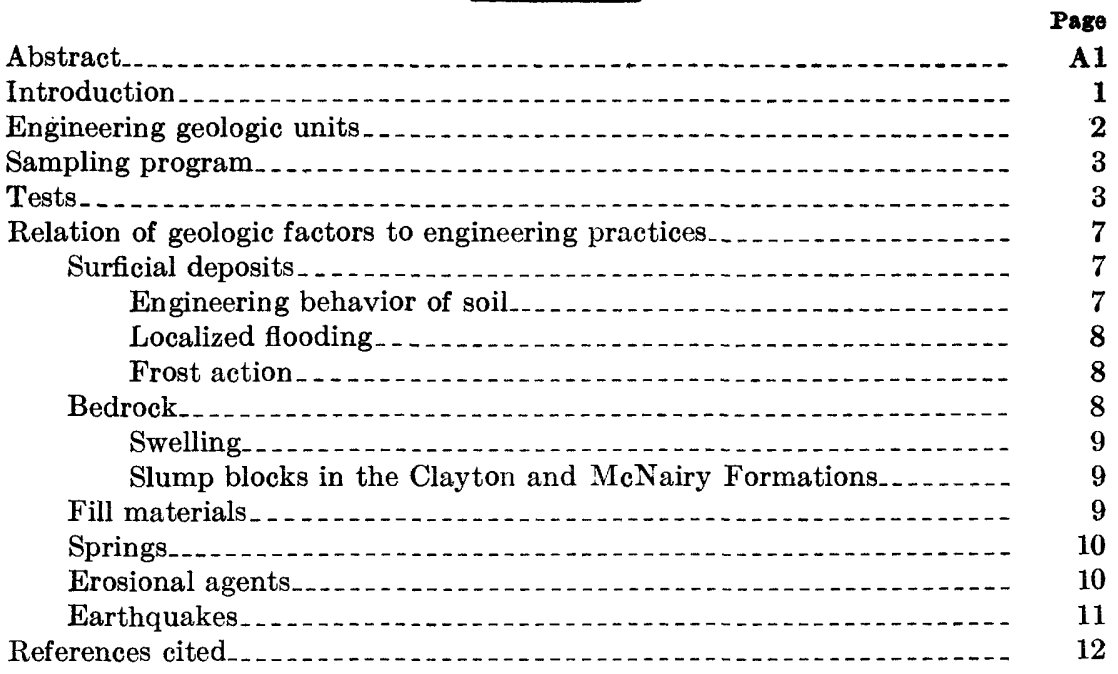

\section{ILLUSTRATION}

Plate 1. Engineering geologic map and sections of the Paducah East quadrangle in Kentucky ...... In pocket

\section{TABLES}

Table 1. General engineering properties and behavior of lithologic units shown on plate 1... In pocket 2. Laboratory test data. 



\title{
CONTRIBUTIONS TO ENGINEERING GEOLOGY
}

\section{ENGINEERING GEOLOGY OF THE PADUGAH EAST QUADRANGLE, IN KENTUGKY}

\author{
By Thomas C. Nichols, JR. \\ ABSTRACT
}

Field and laboratory investigations were conducted to determine the relation of geologic factors to engineering problems. An engineering geologic map delineates surface map units based on engineering properties as well as lithology. Both field and laboratory test procedures and their significance are described. Interpretations are made of the probable behavior of lithologic units, shown on the map, when disturbed by normal engineering and construction practices.

Interpretations are also made of the probable behavior of these same lithologic units in response to natural phenomena such as erosion, flooding, and earthquakes, and the effects of this behavior on existing structures and improvements.

The results of the investigation indicate that the Paducah area has many construction problems related to geologic factors and that site investigations are necessary for efficient land use.

\section{INTRODUCTION}

This investigation of the Paducah East quadrangle was done to show the relation of geologic factors to engineering problems. Quantitative information was collected to describe the behavior and properties of sedimentary materials that make up the units on the geologic map (pl. 1). Qualitative and interpretive information is included to relate geologic phenomena to engineering properties and construction practices. This information is based on field observations and quantitative test results.

This report is not intended to supplant site investigations, but rather to point out some engineering problems that emphasize the need for site investigations. It is directed to the layman as well as to the engineer and geologist.

The study is part of the cooperative program of geologic mapping of Kentucky being conducted by the Kentucky Geological Survey and the U.S. Geological Survey. 


\section{ENGINEERING GEOLOGIC UNITS}

This report and its accompanying map (pl. 1) are based on and supplement the geologic map of the Paducah East quadrangle (Olive, 1966). Much of the quadrangle is covered by surficial deposits which Olive mapped as lacustrine and fluviatile deposits, loess, and continental deposits. The older, bedrock units consist of the Wilcox Formation, Porters Creek Clay, and Clayton and McNairy Formations. To emphasize their lithologic and engineering properties and to better understand their engineering use, Olive's units (see columnar section, pl. 1) have been reclassified for this report and described briefly in the map explanation and columnar section. A description of the engineering properties of each reclassified unit is given in table 1. Units of special interest because of their behavior characteristics are discussed below.

The upper clayey silt phase of the lacustrine and fluviatile deposits is lithologically so similar to the loess deposits mapped by Olive that, in many places, their engineering properties cannot be differentiated (see table 1). Because of the similarities, the lacustrine silt and loess units have been combined on pl. 1 and designated by the symbol MC. A line of columnar sections (pl. 1) has been constructed to show the uniform composition of these deposits.

Gravel deposited as beaches and offshore bars (Finch and others, 1964) occurs in elongate narrow round-crested ridges whose tops are about 355 feet in altitude. These ridges, shown as $G$ on the map, are neither very numerous nor widespread. Gravel, generally having silty or sandy matrix, occurs in the lower part of the lacustrine and fluviatile deposits. It does not crop out in the area, but its position and thickness are shown in the cross section, generalized columnar section, and line of cross sections (pl. 1). The approximate configuration of the upper surface of the gravel is shown on the map by contours. Properties and behavior of the gravel deposits are summarized in table 1.

The continental deposits lie on bedrock surfaces, mostly at an altitude greater than 350 feet above sea level, and consist of generally well-graded chert gravel that has a sandy matrix. Bedding is poorly to well defined. This unit is identified on the map by the symbol Gsc.

The Wilcox Formation has a very limited extent in this quadrangle, but to the west it is much more widespread (Finch, 1964, 1966). Generally, the formation consists of clay and coarse to fine sand. The sand is loose to slightly indurated and has some local crossbedding. The unit is identified on the map by the symbol S.

The Porters Creek Clay consists primarily of a fatty (plastic) clay 
and fine to medium sand. The clay is medium bedded and moderately indurated. At outcrops, conchoidal desiccation fractures are prominent. Sand and clay in the upper 30 feet of the formation are generally medium bedded and slightly to moderately indurated. Tectonic joints are not conspicuous and, in many places, beds appear to be massive. This unit is identified on the map by the symbol Cp.

The Clayton and McNairy Formations are primarily lean clay, silt and sand deposits. Commonly the clay is thin bedded with intercalated laminae of silty sand and the attitude of the bedding planes is nearly flat. In places the sand is thick bedded and occurs in high-standing cliffs. Generally the intercalated clays and sands have some degree of induration, but locally, loose sand occurs in pockets. These formations are identified on the map by the symbol SCM.

\section{SAMPLING PROGRAM}

The sampling program was intended to provide representative samples from all geologic formations to indicate the range of their engineering properties. Where possible, samples were taken from each formation at approximately 1-mile intervals. Most were taken by hand from outcrops below zones of obvious weathering. At several sites, however, the weathered material was deliberately sampled to determine its characteristics. Relatively thick surficial units were sampled at vertical intervals of 10 feet, from top to bottom. Samples to depths of 6 feet were taken from outcrops wherever possible. Elsewhere, samples were taken as deep as 120 feet, using a power auger. Thus, the sample coverage was limited chiefly by scarcity of outcrops and poor accessibility for a truck-mounted auger.

Several techniques were used to take undisturbed as well as disturbed samples. Some undisturbed samples (those that have sustained little or no distortion during sampling) were taken with a ring-lined percussion-type core barrel especially designed for minimum disturbance during sampling. Other undisturbed samples were obtained by trimming, in the laboratory, large samples taken from outcrops by hand. Disturbed samples (those that have been distorted but not disaggregated) were taken with a pick, shovel, other common handtools, and power auger. Remolded samples (those that are completely reworked in the laboratory) were obtained from core barrel, power auger, and hand samples.

\section{TESTS}

The results of field and laboratory tests that were used to provide quantitative information for geologists and engineers may also be useful to nonprofessio als. For this reason, the meaning of each test, 
the test method, and use of the results shown in table 2 will be described briefly. More detailed descriptions can be found in most of the standard soil-engineering textbooks, such as Jumikis (1962) or Sowers and Sowers (1951).

The tests performed (table 2) are designed to predict, at least approximately, the behavior of various geologic formations during excavation or construction activity. Certain tests, such as mechanical analyses, clay-mineral studies, and Atterberg limit tests, determine characteristics of particles that make up a particular unit. Others, such as compressive strength, consolidation, potential volume change, and compaction tests, measure how a mass of those particles reacts to various applied forces and water conditions. Still other tests, such as field bulk-density tests, indicate the natural condition of the geologic unit in the ground.

Mechanical analyses determine the median size and distribution of particle sizes in a soil sample by sieve and hydrometer methods. From these data, the sorting and grain-size distribution of a soil material can be determined which, in turn, can be related to behavior characteristics such as consolidation, porosity, permeability, and shear strength.

Atterberg limits are values of water content that define limits of soil consistency. For this report only two of these limits are used, the plastic limit (PL) and the liquid limit (LL). To determine the plastic limit, water is added to a dry soil until it can be rolled into a plastic thread without breaking. The soil is then at its plastic limit; the PL is recorded in table 2 as a number which is the ratio of the weight of water to weight of dry soil (expressed in percent). Then more water is added until the soil becomes fluid under specified conditions. The soil is then at its liquid limit, which is recorded as a similar ratio. The difference of water content between the plastic limit and the liquid limit defines the range over which the soil is plastic and is called the plasticity index (PI).

The Atterberg limits are useful in predicting engineering properties of a soil. The range of behavior of soils attributed to changes in soil moisture, temperature, mineralogy, consistency, or soil fabric has been empirically very closely related to these limits and to mechanicalanalyses data. For instance, several engineering classifications of soils are based on the liquid limit and grain-size distribution. One of these, the Unified Soil Classification System, is used in table 2.

These limits are also used to compute the "activity" of soils, which simply relates plasticity to the quantity of the clay-size particles present. Skempton (1953a, p. 42) has defined activity as the ratio of the plasticity index to the percentage of the clay-size particles, those smaller than 2 microns. 
The activity is useful for indicating engineering behavior of the same soils, especially the behavior of the clay-size fraction. For instance, if a relatively artive clay mineral such as montmorillonite were predominant in a soil, high activity values would be measured, and such a soil would be considered unstable. Conversely, soils with inactive clays would be relatively stable. Skempton (1953b, p. 59) proposed five groups of activity as listed below:

Group 1. Inactive-activity less than 0.5.

Group 2. Inactive-activity $0.5-0.75$.

Group 3. Normal-activity 0.75-1.25.

Group 4. Active-activity 1.25-2.0.

Group 5. Active-activity greater than 2.0.

Compressive-strengti tests are a measure of the axial stress required to deform an unconfined sample until it fails or until a constant rate of deformation is developed. Compressive strengths are determined on undisturbed and remolded samples by applying an axial load to each specimen until fallure occurs and also by measuring penetration with a penetrometer that is calibrated for compressive strength. Both undisturbed and disturbed samples are tested at natural soilmoisture content (see description of moisture content determination below), and the remolced samples are tested at close to the optimum moisture content (refər to compaction test below). Compressivestrength test data allo' $v$ estimation of consistency and shear strength of cohesive soils, thus ndicating bearing and slope-stability qualities.

Consolidation tests determine soil volume decrease caused by external loading. These tests are performed by loading a saturated, undisturbed sample and observing the decrease in thickness, which is proportional to the change of volume. Loosely compacted soils generally have a larger capability for consolidation than firm, dense soils. Soils that undergo a large percentage of consolidation in the laboratory will probably settle to some extent under load in place and could cause foundation failures. Except in the explanation of plate 1, the term consolidation is used tc denote soil volume decrease caused by external loading.

Potential-volume-change tests measure swelling characteristics of soils. Uniformly compacted samples at controlled initial water contents are saturated under an initial nominal load. Resulting swell pressures are exerted against a proving ring and recorded as swell potentials. Undisturbel samples at natural bulk density and moisture content are similarly 1,ested to obtain swell potentials. The swelling potentials of disturbel soils indicate the swelling behavior of the material as fill, whereas the swelling potentials of the undisturbed soils indicate the swelling behavior of the materials in situ. 
Compaction tests determine the maximum bulk density to which a soil can be mechanically compacted and the amount of soil moisture (optimum moisture content) necessary for such compaction. Samples are tested by uniformly compacting them at successively increasing moisture contents until a maximum density is achieved. Data from such tests can be used to estimate the quantity of water and amount of compaction needed to compact fill material for maximum stability.

Field bulk density is a measure of soil weight per unit volume as it exists in place. This test is made by weighing the soil that is extracted from the ground and measuring the volume of the excavation. From these two measurements the bulk density can be computed. Such data are helpful in evaluating soil consistency, porosity, and permeability.

Frost susceptibility is a prediction of possible frost action based on properties of soils as classified by the Unified Soil Classification (U.S. Federal Housing Administration, Architectural Standards Division, 1959 , p. 19). Soils susceptible to frost action can be expected to cause damage to highways in areas where ground moisture is plentiful and where temperatures near freezing fluctuate for extended periods of time.

Tests to determine the natural moisture content of a soil are performed by calculating the difference in the weight of a sample before and after driving the moisture off by a controlled heat source. Natural moisture contents are helpful in evaluating drainage conditions, frost-heave possibilities, strength, and consolidation properties of the soils tested.

Infiltration tests indicate how rapidly water percolates into the ground. This is done by allowing a known column of water to penetrate a known surface area of ground for a specific length of time. The resulting penetration is expressed as height of water per unit-time absorption. Such data indicate relative runoff, soil permeability, and other drainage conditions.

Analyses of mineral composition determine the minerals that are present in significant quantities. These analyses are accomplished by $\mathrm{X}$-ray diffraction procedures. Such mineralogic data can give valuable insight regarding physical behavior of materials. The clay minerals within a sample can be a critical controlling factor of soil behavior. For example, clay minerals in the montmorillonite group generally are the cause of swelling and heaving problems, whereas other clay minerals are less active and can be considered to be more stable. 


\section{RELATION OF GEOLOGIC FACTORS TO ENGINEERING PRACTICES}

Test results and field observations show that the following geologic factors within the Paducah area definitely affect engineering construction practices.

\section{SURFICIAI DEPOSITS}

Widespread clayey silt deposits of eolian, fluviatile, and lacustrine origin are very uniform in texture and composition both laterally and and vertically (pl. 1). These deposits are the cause of many construction problems in the area. The lacustrine and fluviatile deposits are extensive in low, poorly drained areas and are intermittently nearly saturated by a near-surface ground-water table. Pree, Walker, and MacCary (1957, p. 26) have shown that this water table fluctuates as much as 18 feet a year. At higher elevations, loess deposits form a covering mantle and, because they are more adequately drained, are generally much drier, except where local depressions entrap water.

The thick gravel deposits underlying the lacustrine and fluviatile silts generally offer considerable resistance to a power auger. These deposits should be investigated during site studies for larger structures as possible support for pile foundations.

Gravels in the continental deposits that occur in the higher topographic areas would be excellent support for foundations, large or small. Where covered by thin eolian silt deposits, the gravels would be much more suitable for foundations than the silt.

ENGINEERING BEHAVIOR OF SOIL

The low-lying clay and silt deposits, where subject to saturation, are potentially the most troublesome units. A seasonal variation of the water table and the unfavorable compaction properties of these deposits cause undesirable soil behavior and hazards to existing improvements.

As the water table rises close to the surface and the deposits become saturated, the shearing and bearing strength decreases, and the consolidation and swelling activity increases. When saturated, the soil behaves in a plastic manner (table 2, Atterberg limits), and the strength of the material is attributed chiefly to the lateral confinement and to the soil fabric. Also, because the compaction of these deposits varies greatly, they are subject to significant differential consolidation when surficially loaded. Because of these undesirable engineering properties, damage, such as cracked and sagging walls, is common in many existing structures. 
The higher, drier loess deposits are generally more favorable for construction than similar fine-grained deposits in the low areas. They are generally stronger and have less tendency to swell or consolidate. Compressive strengths of the driest samples taken were as high as 48 tons per square foot (table 2).

However, where there are depressed areas within the loess deposits, the soil-moisture content approaches that of the deposits in the lower undrained areas. Deposits in these areas will have properties similar to those in the lowlands; therefore, it becomes quite important to investigate subsurface moisture and natural drainage conditions before embarking on any construction program.

\section{LOCAIIZED FLOODING}

Poor drainage and low soil permeability of the low-lying deposits are responsible for flooded basements and ponded yards. During the wet seasons of the year and in times of torrential rains, the water table rises to within several feet of the surface. Thus, surface and ground water accumulate in unwaterproofed basements and in topographic depressions that have not been drained properly. Because of the low permeability of these deposits, indicated by the infiltration and percolation tests (table 2), artificial drainage must be provided in order to eliminate such entrapment of water.

\section{FROST ACTION}

Frost action frequently damages highways and roads built on the lacustrine and fluviatile deposits. The most severe damage occurs near stream channels, springs, and poorly drained areas where there is a constant near-surface water supply. Repeated freeze-thaw tests (Finch, 1968) of a sample of silt from the Paducah area showed that when sufficient soil moisture was available, the sample volume increased and the density and strength decreased after each repeated test. According to Johnson (1952, p. 17-22), these results are in accord with other investigators who agree that frost action becomes more severe with each additional freeze-thaw cycle and with abundance of available water. In the Paducah area, the climate is favorable for many freeze-thaw cycles, and the frost penetration is generally about 5 inches. Therefore conditions are favorable for freeze-thaw damage to roads.

\section{BEDROCK}

The poorly indurated bedrock formations are generally stronger, more compact, and less active than the surficial deposits. The following unfavorable behavior occurs in the bedrock. 
SWEIIING

In most lithologic units that remain relatively undisturbed adjacent to excavations, swelling problems may occur but probably will be less noticeable than in fill deposits of the same material. Under this condition, the water content remains more uniform, and the natural geologic fabric of the material tends to restrict swelling activity. However, where exposed, deposits having large quantities of swelling clays have critical behavior in situ. For instance, in such deposits as the clayey lower part of the Porters Creek Clay, which consists of as much as 70 percent montmorillonite, swelling and volume-change conditions are critical wherever the unit is exposed. In dry weather, exposure causes desiccation, and large volume decreases take place; in wet weather, swelling occurs, and large volume increases take place. Where this deposit is not exposed, the low permeability, indurated fabric, and overburden loads restrict any rapid changes of water content, and volume change is held to a minimum.

\section{SLOMP BLOCKS IN THE CLAYTON AND MONAIRY FORMATIONS}

Along the Clarks River, southwest of sample site 14 shown on plate 1, and along the south bank of the Tennessee River, are ancient and recent slump blocks within the Clayton and McNairy Formations. Where the thinly bedded fine sand and clay of the Clayton and McNairy Formations are exposed, undercutting by rivers and streams has triggered massive block sliding. In similar locations where sliding has not yet occurred, internal forces are probably barely in equilibrium, and any combination of erosional undercutting or appreciable surface loading could easily trigger additional slides.

\section{FIIL MATERIALS}

When the natural state of a deposit is disturbed, the properties of the materials change considerably. Geologic deposits, accordingly, are generally more favorable for foundations when in place than after they have been moved and used as fill material. In fine-grained materials, generally, the strength decreases and, as the bulk density decreases, the swelling capacity, permeability, and porosity increase. Each of these factors contributes to the instability of fill material, even if it is compacted to maximum density by heavy construction equipment.

In the Paducah area, a pronounced change of swelling properties takes place where the natural deposits are excavated and then compacted as fill deposits. This change is corroborated by laboratory tests which show increased swelling pressures of remolded specimens derived 
from the geologic units that contain significant quantities of clay. As the data in table 2 show, the units showing the greatest increase in the potential volume-change swell index in the remolded specimens are those that have a high proportion of clay minerals and very small median particle size. Also, in these swelling materials, the mixedlayer clays, consisting primarily of montmorillonite and vermiculite, are present in large quantities. As previously stated, these are the clay minerals that will cause excessive swelling.

On the basis of this evidence, fill materials derived from the silt and clay deposits can be expected to have troublesome swelling problems. Sloughing on fill slopes and some irregularities of pavement surfaces constructed on fills can probably be attributed to swelling clays.

\section{SPRINGS}

Springs can be very destructive to manmade structures. Generally they result from recognizable geologic relationships that can and should be determined before any major construction takes place. Their location is often related to abrupt changes in the lithology of deposits. For instance, in the Paducah area, it is common for permeable silts, sands, and gravel to directly overlie impermeable clays. The permeable layers provide excellent storage for ground water. Wherever the contact of permeable beds overlying impermeable beds crops out, there is likely to be a spring at its lowest point. Springs occur around Paducah (see pl. 1) and have been known to cause severe road damage where spring water continually undermines the road base. Therefore, in areas where springs exist or can be predicted, construction plans should be prepared to avoid the possibility of damage.

\section{EROSIONAL AGENTS}

Frequent heavy seasonal rainfall and flooding are very active erosional agents in the Paducah area. Heavy rains can rapidly erode unprotected slopes. Fresh gullying and sloughing is commonly observed on unprotected slopes of the widespread silty soils. Such erosion is a continuing highway maintenance problem.

Flooding by the rivers is a major destructive force. Before 1945, according to Finch (1968), major floods had occurred in 1884, 1913, and 1937. Flood crest of the Ohio River at Paducah is 39 feet, or 324.96 feet above sea level. In 1884 , the river crested at 54.20 feet, in 1913 at 54.30 feet, and in 1937 at 60.60 feet. Damage caused by these floods was extensive. Since 1937, flood-control measures have been taken to avoid such damage. A floodwall was constructed around the city of Paducah, as shown on plate 1, to an elevation of 350 feet above sea level. The Kentucky dam was completed across 
the Tennessee River in 1945 in an effort to control the volume of water that empties into the Ohio River. Since 1945, floods have occurred every year except 1953 and 1954 (Finch, 1968), but all except one have crested at less than 50 feet. In 1950, the Ohio River crested at 53.31 feet. In every case, the floodwall was high enough to prevent damage within the city of Paducah. Thus, any construction that takes place outside the floodwall will be susceptible to the ravages of flooding, unless such construction takes place at elevations higher than that of any probable future flood level.

Flooding and high water levels in streams and rivers also give rise to strong currents and increased pore water pressures that are very effective erosional agents, especially in silts. These erosional forces have undermined silt banks along the Tennessee River and threaten to destroy some roads and buildings.

Rapid drops in water level, caused by the rapid lowering of flood crests and by periodic closing of the Kentucky dam probably accelerate erosion of silt deposits. Pore water pressures attained at high water levels are not rapidly dissipated as the water level drops. They tend to work against the soil particles, causing sloughing and slumping.

\section{EARTHQUAKES}

As evidenced by the New Madrid earthquake in 1811 (Fuller, 1912, p. 17) and numerous tremors since then (Finch, 1968), Paducah is in an active seismic area. The New Madrid earthquake was so severe that the shock was felt in an area of more than a million square miles (Fuller, 1912, p. 17). In the New Madrid region, according to Fuller, this quake had catastrophic effects in an area of about 50 by 100 miles. The village of New Madrid was badly damaged, and Little Prairie was virtually destroyed. The ground-wave motion was very strong, the ground rising and falling like the long, low swell of the sea. Land slides were common on the steeper bluffs and hillsides, and many large areas either were uplifted or depressed. Great waves on the Mississippi capsized small boats and washed other boats onshore.

If such earth movements were to occur today in the highly populated areas along the Mississippi and Ohio rivers, destruction of property and lives would probably be very great. According to the Uniform Building Code (International Conference of Building Officials, 1964) the Paducah area is in a zone of probable seismic activity of 3 , indicating that earthquakes in the area are likely to be of a magnitude great enough to cause major damage. Buildings in the area should be designed for maximum earthquake forces according to the detailed design information described in the code. 


\section{REFERENCES CITED}

American Society for Testing Materials, Committee D-18 on Soils for Engineering Purposes, 1964, Procedures for testing soils [4th ed.]: Philadelphia, Am. Soc. Testing Materials, $540 \mathrm{p}$.

Browne, R. G., and Herrick, S. M., 1963, Smaller Paleocene Foraminifera from Reidland, Kentucky: Bulls. Am. Paleontology, v. 46, no. 210, p. 247-284.

Finch, W. I., 1964, Geology of the Symsonia quadrangle, Kentucky: U.S. Geol. Survey Geol. Quad. Map GQ-326.

- 1966, Geologic map of the Paducah West and part of the Metropolis quadrangles, Kentucky-Illinois: U.S. Geol. Survey Geol. Quad. Map GQ-557.

- 1968, Engineering geology of the Paducah West and Metropolis quadrangles in Kentucky: U.S. Geol. Survey Bull. 1258-B, $19 \mathrm{p}$.

Finch, W. I., Olive, W. W., and Wolfe, E. W., 1964, Ancient lake in western Kentucky and southern Illinois, in Geological Survey research 1964: U.S. Geol. Survey Prof. Paper 501-C, p. C130-C133.

Fisk, H. N., 1944, Geological investigation of the alluvial valley of the lower Mississippi River: Vicksburg, Miss., Mississippi River Comm., 78 p.

Fuller, M. L., 1912, The New Madrid earthquake: U.S. Geol. Survey Bull. 494, 119 p.; repr. 1958, Cape Girardeau, Mo., Ramfre Press.

Holtz, W. G., and Gibbs, H. J., 1958, Suggested method of test for consolidation of soils, in American Society Testing Materials, Committee D-18 on Soils for Engineering Purposes, Procedures for testing soils [3d ed.]: Philadelphia, Am. Soc. Testing Materials, p. 296-307.

International Conference of Building Officials, 1964, Uniform building code: Pasadena, Calif., v. 1, 503 p.

Jillson, W. R., 1930, Oil and gas in western Kentucky: Kentucky Geol. Survey ser. 6 , v. 39,632 p. [1931].

Johnson, A. W., compiler, 1952, Frost action in roads and airfields; a review of the literature, 1765-1951: Natl. Research Council, Highway Research Board Spec. Rept. 1, 287 p.

Jumikis, A. R., 1962, Soil mechanics: New York, D. Van Nostrand Co., 791 p.

Lambe, T. W., 1960, The character and identification of expansive soils: U.S. Federal Housing Admin. Tech. Studies Rept. FHA-701, 46 p.

Loughridge, R. H., 1888, Report on the geological and economic features of the Jackson's Purchase region, embracing the counties of Ballard, Calloway, Fulton, Graves, Hickman, McCracken, and Marshall: Frankfort, Kentucky Geol. Survey, 357 p.

McQueen, I. S., 1963, Development of a hand portable rainfall-simulator infiltrometer: U.S. Geol. Survey Circ. 482, $16 \mathrm{p}$.

Olive, W. W., 1966, Geologic map of the Paducah East quadrangle in western Kentucky: U.S. Geol. Survey Geol. Quad. Map GQ-531.

Pree, H. L., Jr., Walker, W. H., and MacCary, L. M., 1957, Geology and groundwater resources of the Paducah area, Kentucky: U.S. Geol. Survey WaterSupply Paper 1417, 214 p.

Skempton, A. W., 1953a, Soil mechanics in relation to geology: Yorkshire Geol. Soc. Proc., pt. 1, v. 29, p. 33-62.

1953b, The colloidal "activity" of clay: Internat. Conf. Soil Mechanics and Found. Eng., 3d, Switzerland 1953, Proc., v. 1, p. 57-61. 
Sohn, I. G., Herrick, S. M., and Lambert, T. W., 1961, Replaced Paleocene Foraminifera in the Jackson Purchase area, Kentucky, in Short papers in the geologic and hydrologic sciences: U.S. Geol. Survey Prof. Paper 424-B, p. B227-B228.

Sowers, G. B., and Sowers, G. F., 1951, Introductory soil mechanics and foundations: New York, Macmillan Co., $284 \mathrm{p}$.

Staplin, F. L., 1963, Pleistocene Ostracoda of Illinois-Part II, Subfamilies Cyclocyprinae, Cyprodopinae, Ilyocyprinae, families Darwinulidae and Cytheridae; stratigraphic ranges and assemblage patterns: Jour. Paleontology, v. 37 , no. 6, p. 1164-1203, pl. 159-160.

U.S. Bureau of Reclamation, 1963, Earth manual [1st ed., revised]: Denver, $783 \mathrm{p}$.

U.S. Federal Housing Administration, Architectural Standards Division, 1959, Engineering soil classification for residential developments: Washington, D.C., Federal Housing Adm. Pub. 373, 107 p.

Wentworth, C. K., 1922, A scale of grade and class terms for clastic sediments: Jour. Geology, v. 30, no. 5, p. 377-392. 
, 

